\title{
Hemotropic mycoplasmas in bats from forest fragments, state of Paraná, southern Brazil
}

\section{Detecção e caracterização de micoplasmas hemotrópicos em morcegos de fragmentos florestais, Paraná, Sul do Brasil}

\author{
Flávia Carolina Meira Collere'; Larissa Dantas Roeder Ferrari²; Ricardo Nascimento \\ Drozino3; Jéssica Damiana Marinho Valente ${ }^{4}$; Paula Fernanda Massini5; \\ Flávio Haragushiku Otomura6; Max Jean de Ornelas Toledo7; \\ Thállitha Samih Wischral Jayme Vieira4; Rafael Felipe da Costa Vieira ${ }^{8 *}$
}

\section{Highlights}

Bats as reservoir of several pathogens of concern for human and animal health. Human's 'Candidatus Mycoplasma haematohominis' probably has its natural host in bats. Hemotropic Mycoplasma spp. has been poorly reported in bats.

\begin{abstract}
The order Chiroptera is the second largest group of mammals with bats being identified as reservoir of several viral zoonoses, although, little is known about their role in other groups of pathogens, including hemotropic Mycoplasma spp. To date, hemoplasma species have been found infecting several species of bats with high genetic diversity between 16S rRNA gene sequences. On this study, we aimed to identify the occurrence and characterize 16S and 23S rRNA genes of hemoplasma species in four bats species (Artibeus lituratus, Carollia perspicillata, Sturnira lilium and Sturnira tildae) from forest fragments in Paraná State, southern Brazil, using PCR-based assays. Spleen tissue samples were collected, DNA extracted

1 Student of the master's degree Program in Veterinary Sciences, Vector-Borne Diseases Laboratory, Departament of Veterinary Medicine, Universidade Federal do Paraná, UFPR, Curitiba, PR, Brazil. E-mail: flavia.collere@ufpr.br

2 Student of the doctoral's degree Program in Veterinary Sciences, Vector-Borne Diseases Laboratory, Departament of Veterinary Medicine, UFPR, Curitiba, PR, Brazil. E-mail: larissadr@gmail.com

3 Researcher, Universidade Estadual de Maringá, UEM, Maringá, PR, Brazil. E-mail: rndrozino@gmail.com

${ }^{4}$ Reseracher, Vector-Borne Diseases Laboratory, Departament of Veterinary Medicine, UFPR, Curitiba, PR, Brazil. E-mail: jessica.d.02@hotmail.com; thallitha.vieira@ufpr.br

5 Profa ${ }^{\mathrm{Dr}}$, Departamento de Medicina Veterinária Preventiva, Universidade Estadual de Londrina, UEL, Londrina, PR, Brazil. E-mail: paulavet massini@hotmail.com

6 Prof. Dr., Universidade Estadual do Norte do Paraná, UENP, Bandeirantes, PR, Brazil. E-mail: otomuraflavio@uenp. edu.br

7 Prof. Dr., UEM, Maringá, PR, Brazil. E-mail: mjtoledo@uem.br

8 Prof. Dr., Postgraduate Program in Veterinary Sciences, Vector-Borne Diseases Laboratory, Departament of Veterinary Medicine, UFPR, Curitiba, PR, Brazil. E-mail: rvieira@ufpr.br

* Author for correspondence
\end{abstract}

Received: Aug. 31, 2021 - Approved: Nov. 09, 2021 
and further screened by a pan-hemoplasma PCR assay. All samples consistently amplified the mammal endogenous gapdh gene. One out of 15 (6.66\%; 95\% Cl: 0.2-31\%) bats tested positive for hemotropic Mycoplasma sp. by the PCR assay targeting the 16S rRNA gene. Sequencing of the 16S rRNA gene fragment from the hemoplasma-positive bat showed $99.14 \%$ identity with hemotropic Mycoplasma sp. detected in Sturnira parvidens from Belize. Sequencing of the 23S rRNA gene fragment from the hemoplasma-positive bat showed $86.17 \%$ identity with 'Candidatus Mycoplasma haemosphiggurus' detected in orange-spined hairy dwarf porcupines (Sphiggurus villosus) from Southern Brazil.

Key words: Bats. Hemotropic mycoplasmas. Hemoplasmas. Mycoplasma sp.

\section{Resumo}

A ordem Chiroptera é considerada a segunda maior ordem de mamíferos do mundo, sendo os morcegos identificados como reservatórios de diversas zoonoses de origem viral, contudo, pouco se sabe sobre seu papel em outros grupos de patógenos, incluindo Mycoplasma spp. Até o momento, Mycoplasma sp., foi encontrado infectando várias espécies de morcegos ao redor do mundo, com alta diversidade genética entre sequências de genes 16S rRNA. O objetivo do presente estudo foi detectar a infecção por hemoplasmas em quinze morcegos insetívoros de quatro diferentes espécies (Artibeus lituratus, Carollia perspicillata, Sturnira lilium and Sturnira tildae) provenientes de fragmentos florestais dos municípios de Mandaguaçu, Maringá e Paiçandu, no Estado do Paraná, sul do Brasil. Amostras de tecido foram coletadas e o DNA extraído, para posterior análise por PCR para detecção de hemoplasmas. Todas as amostras amplificaram o gene gapdh. Um morcego, do total de 15 (6.66\%; 95\% Cl: 0.2-31\%), foi positivo para Mycoplasma sp. na análise do gene16S rRNA. O sequenciamento deste fragmento genético mostrou 99,14\% de identidade com Mycoplasma sp. detectado em Sturnira parvidens em Belize. O sequenciamento do fragmento do gene 235 rRNA do morcego positivo mostrou $86,17 \%$ de identidade com 'Candidatus Mycoplasma haemosphiggurus' detectado em ouriço-cacheiro (Sphiggurus villosus) no sul do Brasil.

Palavras-chave: Morcegos. Micoplasmas hemotrópicos. Hemoplasmas. Mycoplasma sp.

\section{Introduction}

Hemotropic

mycoplasmas

(hemoplasmas) are small pleomorphic Gramnegative bacteria lacking a cell wall that are obligate parasites of red blood cells in a wide range of mammals worldwide. They may cause immune-mediated hemolytic anemia (Millán, Di Cataldo, Volokhov, \& Becker, 2020). In Brazil, hemotropic Mycoplasma spp. have been reported in several wild mammals, including neotropical bats (Ikeda et al., 2017; Santos et al., 2020).

The order Chiroptera is considered to be the second largest group of mammals in the world, with more than 1,200 species present on all continents except Antarctica (Schipper et al., 2008). Bats have been widely studied as reservoir hosts for zoonotic pathogens (Volokhov et al., 2017; Millán, López-Roig, Delicado, Serra-Cobo, \& Esperón, 2015), although whether bats are equally competent hosts of non-viral pathogens, such as bacteria, remains an open and unanswered question (Volokhov et al., 2017; Brook \& Dobson, 2014). In this regard, the numbers of studies on hemoplasmas infecting bats have been increasing over the past decade. Previous studies showed that hemoplasmas were common in little brown bats (Myotis lucifugus) in eastern and northeastern USA (Mascarelli et al., 2014). Additionally, the prevalence of 
hemotropic Mycoplasma spp. was found to be $97 \%$ in Schreibers's bats (Miniopterus schreibersii) in Spain (Millán et al., 2015), 67\% in vampire bats (Desmodus rotundus) in Peru and Belize (Volokhov et al., 2017), 83.33\% in D. rotundus in Brazil (Santos et al., 2020), 26.66\% in molossids (Molossus molossus and $M$ nigricans) in Brazil (Ikeda et al., 2017) and 60\% in fruit bats (Eidolon sp.) in Nigeria (Di Cataldo Kamani, Cevidanes, Msheliza, \& Millán, 2020).

Several 16S rRNA gene sequences from hemotropic Mycoplasma spp. that are phylogenetically related to known hemoplasma species have been identified in bats. Sequences with similarity to Mycoplasma coccoides in molossids in Brazil (Ikeda et al., 2017), 'Candidatus Mycoplasma haematohominis' in Miniopterus schreibersii in Spain (Millán et al., 2015) and Pteropus spp. in New Caledonia (Descloux et al., 2020), along with other potentially novel hemoplasma genotypes, have been described in bats (Millán et al., 2020). However, due to the high genetic diversity between 16S rRNA gene sequences from hemoplasmas found in bats, studies involving other genes of this group of bacteria are needed in order to better characterize the species. Accordingly, the aim of the present study was to identify and characterize $16 S$ and 235 rRNA genes of hemoplasma species occurring in four bat species (Artibeus lituratus, Carollia perspicillata, Sturnira lilium and Sturnira tildae) from forest fragments in the state of Paraná, southern Brazil, using PCR-based assays.

\section{Materials and Methods}

\section{Ethical approval}

This study was approved by the Ethics Committee for Animal Experimentation and
Animal Welfare of the Federal University of Paraná, Brazil (protocol number 053/2018). The animal and laboratory procedures were approved by the Chico Mendes Institute for Biodiversity Conservation (ICMBio, protocol number 63433).

\section{Study area and sampling}

The study was carried out in an urban public park in the city of Maringá: Ingá Park (23 $25^{\prime} 48.4^{\prime \prime} \mathrm{S} 51^{\circ} 55^{\prime} 43.2^{\prime \prime} \mathrm{W}$ ) and rural areas of the municipalities of Mandaguaçu (23 19' 4.6"

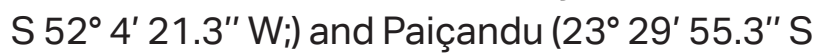
$\left.52^{\circ} 8^{\prime} 16.1^{\prime \prime} \mathrm{W}\right)$, in Paraná. The areas studied are located in the northwestern region of Paraná, which is characterized by semideciduous Atlantic Forest fragments. This region has a subtropical climate with an average temperature of $21.7^{\circ} \mathrm{C}$. The areas studied have diverse fauna that commonly includes populations of capybaras (Hydrochoerus hydrochaeris), non-human primates, reptiles, Didelphis spp., Nasua nasua and bats, as well as a wide variety of birds and fishes.

A total of 15 bats (five females and 10 males) were caught during September 2018 and March 2019 using mist nets. These were placed along natural or artificial trails and kept there for six-hour periods that straddled sunset time. The nets were checked every $30 \mathrm{~min}$. The capture effort was 3.240 square hectometers. Four out of these 15 bats (26.7\%) were caught in the rural area of the municipality of Mandaguaçu, six (40\%) in Ingá Park and five (33.3\%) in the rural area of the municipality of Paiçandu. These bats were placed in individual cloth bags, chemically restrained (xylazine 4.0 $\mathrm{mg} / \mathrm{kg}$ and ketamine $20.0 \mathrm{mg} / \mathrm{kg}$ ), euthanized using isoflurane in a carbon dioxide chamber and identified at the species level (Reis, 
Peracchi, Batista, Lima, \& Pereira, 2017). Four species were identified: Artibeus lituratus (7/15; 46.67\%), Carollia perspicillata (2/15; $13.33 \%)$, Sturnira lilium (4/15; 26.67\%) and Sturnira tildae (2/15; 13.33\%). Spleen fragment samples were collected, labeled and stored at $-80^{\circ} \mathrm{C}$ until the time of molecular analyses.

\section{DNA extraction and $P C R$ assays}

DNA was extracted from spleen fragment samples using a commercial kit (QIAamp ${ }^{\mathrm{TM}}$ DNA micro-kit, Qiagen, Hilden, Germany), in accordance with the manufacturer's instructions. Ultrapure water was used as a negative control in parallel, to monitor for cross-contamination.

A conventional PCR to investigate the mammalian endogenous gene glyceraldehyde-3-phosphate dehydrogenase (gapdh) (Birkenheuer, Levy, \& Breitschwerdt, 2013) was performed to ensure successful DNA extraction. Thereafter, all DNA samples were screened by means of a genus-specific PCR assay targeting a fragment $(900 \mathrm{bp})$ of the 16S rRNA gene of hemoplasmas (Hoelzle et al., 2011; Machado et al., 2017). Bat DNA samples that were found to be positive in the screening PCR assay based on 16S rRNA were subjected to a genus-specific PCR assay targeting a fragment (800 bp) of the $23 \mathrm{~S}$ rRNA gene of hemoplasmas (Mongruel et al., 2020). Nuclease-free water and Mycoplasma ovis DNA from a naturally infected goat blood sample were used as negative and positive controls, respectively, in both PCR assays. The amplified PCR products were subjected to electrophoresis on stained $1.5 \%$ agarose gel (SYBR ${ }^{\circledR}$ Safe DNA gel stain, Invitrogen) for 50 $\min$ at $100 \mathrm{~V}$ and then visualized.
Sequencing and phylogenetic analysis

Amplicons of the 16S rRNA and 23S rRNA genes obtained from one hemotropic Mycoplasma sp.-positive sample were sequenced in both directions using the Sanger method, with nucleotide sequences of the 16S rRNA and 23S rRNA genes of hemotropic Mycoplasma sp. submitted to the GenBank ${ }^{\circledR}$ database (accession numbers: MN170512 and MN172169).

The partial sequences of the $16 \mathrm{~S}$ and 23S rRNA genes of hemotropic Mycoplasma spp. were aligned using MAFFT 7.110 (Katoh \& Standley, 2013) on the Guidance 2 server (Drummond, Suchard, Xie, \& Rambaut, 2012), for each gene. Phylogenetic analyses on the $16 \mathrm{~S}$ and $23 \mathrm{~S}$ genes were performed based on Bayesian inference (BI) using the Beast 1.8.0 package (Drummond et al, 2012). Three independent runs of $100,000,000$ generations of Monte Carlo Markov Chain (MCMC) were performed, with one sampling per 10,000 generations and a 10\% burn-in. The substitution models were estimated as $\mathrm{GTR}+\mathrm{G}$ for the $16 \mathrm{~S}$ rRNA gene and $\mathrm{GTR}+\mathrm{I}+\mathrm{G}$ for the 23S rRNA gene, based on the Akaike information criterion (AIC) using jModeltest 2.1.10 (Darriba, Taboada, Doallo, \& Posada, 2012). Reconstructions were visualized using the FigTree 1.4.4 software (Sela, Ashkenazy, Katoh, \& Pupko, 2015). The $16 \mathrm{~S}$ rRNA gene and 23S rRNA gene trees were rooted with Mycoplasma pneumoniae (NZ_CP008895).

\section{Results and Discussion}

All the samples consistently amplified the mammalian endogenous gapdh gene. One out of 15 bats (6.66\%; 95\% Cl: 0.2-31\%) tested positive for hemotropic Mycoplasma 
$\mathrm{sp}$. in the PCR assay targeting the 16S rRNA gene. Sequencing of the 16S rRNA gene fragment from the hemoplasma-positive bat showed $99.14 \%$ identity with hemotropic Mycoplasma sp. detected in a bat (Sturnira parvidens) (MH245137) in Belize, Central America, 98.90\% identity with hemotropic Mycoplasma sp. (MH245136) detected in Uroderma bilobatum in Belize, and 98.29\% identity with multiple hemotropic Mycoplasma sp. (KY932674, KY932675, KY932677, KY932678, KY932679, KY932680) detected in $D$. rotundum in Belize and Peru, with $100 \%$ query cover. Sequencing of the 23S rRNA gene fragment from the hemoplasmapositive bat showed $86.17 \%$ identity with 'Candidatus Mycoplasma haemosphiggurus' detected in orange-spined hairy dwarf porcupines (Sphiggurus villosus) (MN692881 and MN164485) in southern Brazil and $80.46 \%$ identity with Mycoplasma haemofelis (CP002808, FR773153, NR_103993).

Phylogenetic analysis on the 16S rRNA and 235 rRNA genes of the bat hemoplasma detected in the present study clustered together with those of the M. haemofelis group (Figure 1 and Figure 2). Different branches were demonstrated in the phylogenetic analysis on 16S rRNA gene fragments from hemoplasmas previously detected in bats (Figure 1). The phylogenetic analysis showed that there was a close relationship between the $A$. lituratus hemoplasma detected here and the hemotropic Mycoplasma spp. detected in Sturnira parvidens and Uroderma bilobatum bats in Belize (Figure 1).

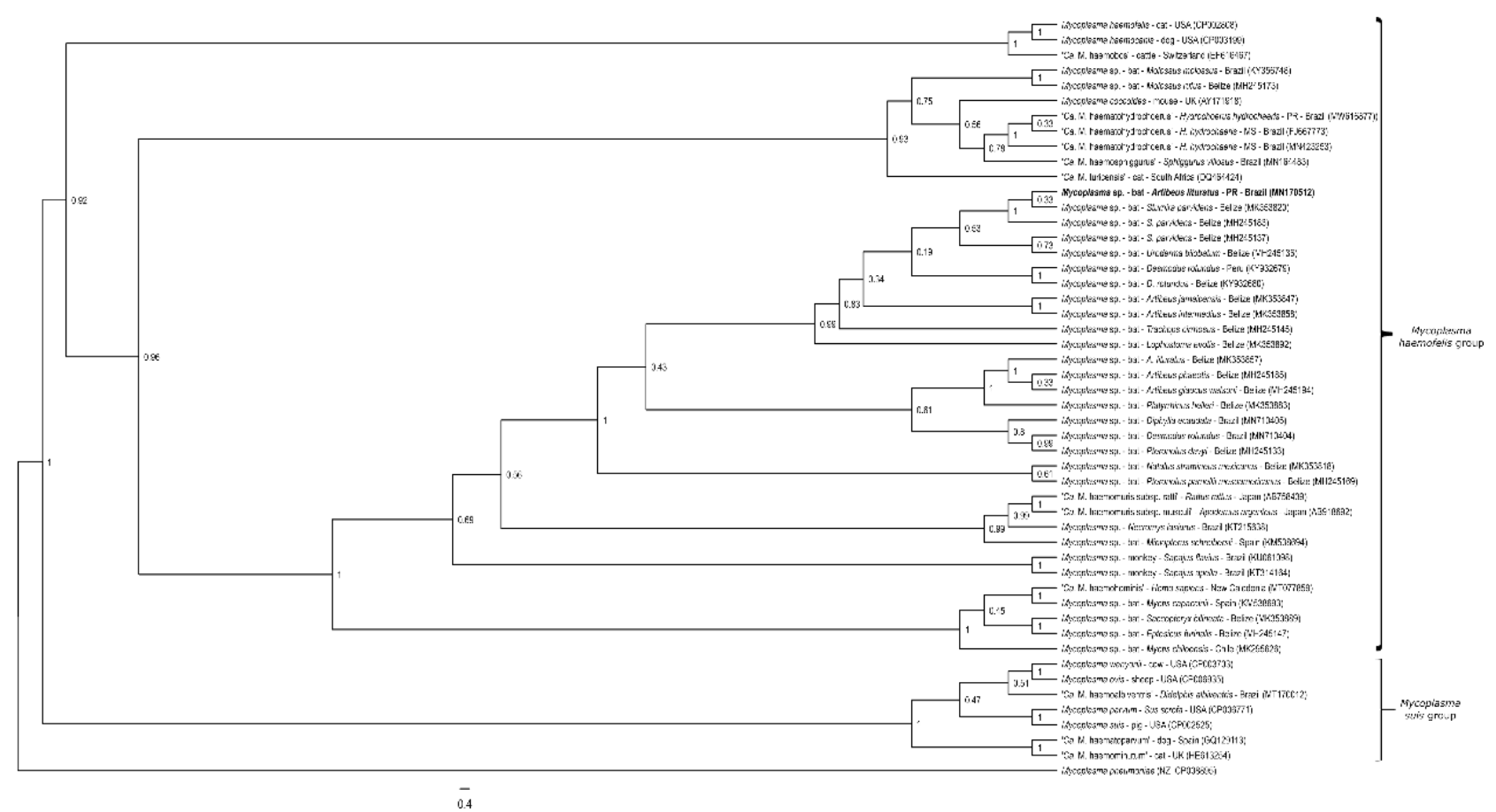

Figure 1. Phylogenetic tree based on partial sequences ( 900 bp) of the 16S rRNA gene. The phylogenetic tree was inferred by using Bayesian inference (BI). The substitution models were estimated as GTR+G for the 16S rRNA gene, based on the Akaike information criterion (AIC) using jModeltest 2.1.10.. The sequence detected in the present study is highlighted in bold. Mycoplasma pneumoniae was used as an outgroup. Branch lengths represent units of substitutions per site. 


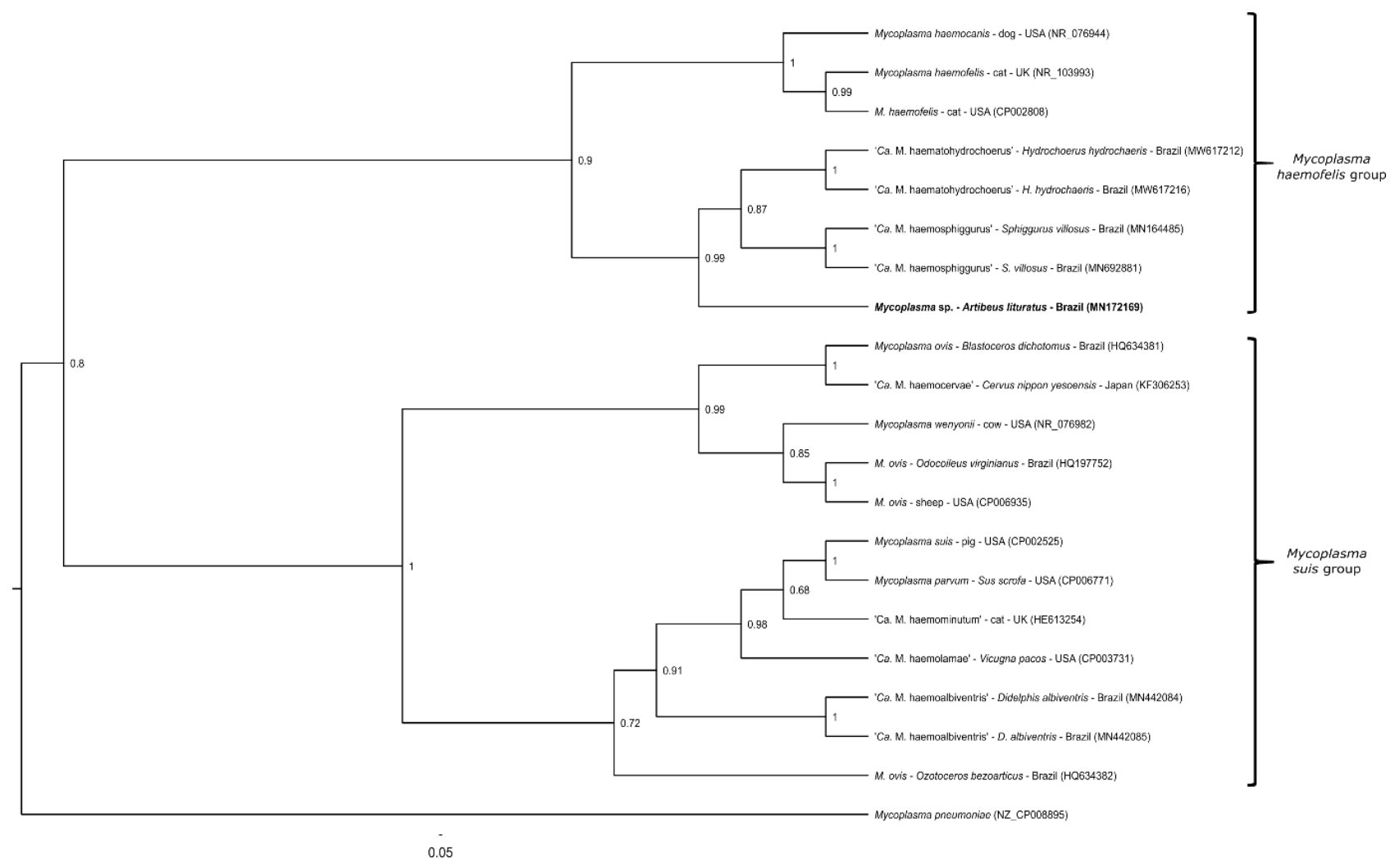

Figure 2. Phylogenetic tree based on partial sequences ( 620 bp) of the 23S rRNA gene. The phylogenetic tree was inferred by using Bayesian inference (BI). The substitution models were estimated as GTR+I+G for the 23S rRNA gene, based on the Akaike information criterion (AIC) using jModeltest 2.1.10. The sequence detected in the present study is highlighted in bold. Mycoplasma pneumoniae was used as an outgroup. Branch lengths represent units of substitutions per site.

High genetic diversity among 165 rRNA gene sequences from hemoplasmas detected in bats in 12 countries has been described (Millán et al., 2020). In rodents, high genetic diversity between hemoplasmas has also been found (Alabí et al., 2020). A previous study on bats in Brazil found hemotropic Mycoplasma sp. genotypes that were closely related to previously reported genotypes detected in rodents (Ikeda et al., 2017). From an evolutionary point of view, bats and rodents are large groups belonging to ancient orders of mammals that have shown high adaptation as hosts for different groups of pathogens. Here, the 16S rRNA gene sequence from the A. lituratus hemoplasma was seen to branch away from rodent hemoplasmas (Figure 1). Moreover, a hemotropic Mycoplasma sp. detected in $A$. lituratus in Belize was also seen to branch away from the hemoplasma sequence detected in this bat species in Brazil.

In order to better characterize the hemoplasma species infecting bats, we amplified and sequenced a fragment of the $23 S$ rRNA gene. However, since there are no other closely related hemoplasma 23S rRNA 
gene sequences available in the GenBank $^{\circledR}$ database, the bat hemoplasma 23S rRNA gene detected herein showed only $86 \%$ identity with the $23 \mathrm{~S}$ rRNA gene of ' $\mathrm{Ca}$. M. haemosphiggurus' detected in orange-spined hairy dwarf porcupines (Sphiggurus villosus) in southern Brazil (Figure 2). Further studies targeting other genes (RNaseP, rpoB, gyrB) and/or whole genome sequencing should be performed in order to assess the phylogenetic positioning of bat hemoplasma species.

Previous studies found that hemoplasmas were highly frequent in Schreibers's bats (Miniopterus schreibersii) in Spain (Millán et al., 2015), vampire bats ( $D$. rotundus) in Peru, Belize and Brazil (Volokhov et al., 2017; Santos et al., 2020), molossids (Molossus molossus and $M$. nigricans) in Belize and Brazil (Ikeda et al., 2017; Becker et al., 2020) and Eidolon fruit bats in Nigeria (Di Cataldo et al., 2020). However, in other studies, hemotropic Mycoplasma spp. was not found infecting Pipistrellus pipistrellus and P. kuhlii (Ikeda et al., 2017; Becker et al., 2020). In this regard, a recent study suggested that some bat species may be resistant to infection or have ecological characteristics that reduce their exposure to hemotropic Mycoplasma spp. (Millán et al., 2020). Here, only one out of 15 bats tested positive for hemoplasma. Therefore, future studies sampling higher numbers of bats are needed in order to elucidate that hypothesis.

\section{Conclusion}

Hemoplasmas are uncommon in bats from the forest fragment areas of the present study, in the state of Paraná, southern Brazil.
Phylogenetic analysis on the 16S rRNA gene showed that the $A$. lituratus hemoplasma detected here had a close relationship with hemotropic Mycoplasma spp. detected in S. parvidens and U. bilobatum bats in Belize.

\section{Acknowledgements}

Flávia C. M. Collere was sponsored by a fellowship from the the Coordenação de Aperfeiçoamento de Pessoal de Nível Superior (CAPES) at the time of research. The Brazilian National Council of Scientific and Technological Development (CNPq) provided a fellowship of research productivity (PQ) to Dr. Rafael F.C. Vieira (CNPq - 313161/2020-8).

\section{Funding}

No funding was used for this research

\section{Conflict of interest}

The authors declare that they have no conflict of interest.

\section{Ethics approval}

This study was approved by the Ethics Committee for Animal Experimentation and Animal Welfare of the Federal University of Paraná, Brazil (protocol number 053/2018). The animal and laboratory procedures were approved by the Chico Mendes Institute for Biodiversity Conservation (ICMBio, protocol number 63433). 


\section{References}

Alabí, A. S., Monti, G., Otth, C., SepulvedaGarcía, P., Sánchez-Hidalgo, M., Mello, V. V. C. de,... Müller A. (2020). Molecular survey and genetic diversity of hemoplasmas in rodents from Chile. Microorganisms, 8(10), 1493. doi: 10 3390/microorganisms8101493

Becker, D. J., Speer, K. A., Brown, A. M., Fenton, M. B., Washburne, A. D., Altizer, S.,... Volokh, D. V. (2020). Ecological and evolutionary drivers of haemoplasma infection and bacterial genotype sharing in a Neotropical bat community. Molecular Ecology, 29(8), 1534-1549. doi: 10.1111/ mec.15422

Birkenheuer, A. J., Levy, M. G., \& Breitschwerdt, E. B. (2003). Development and evaluation of a seminested PCR for detection and differentiation of Babesia gibsoni (Asian genotype) and $B$. canis DNA in canine blood samples. Journal of Clinical Microbiology, 41(9), 4172-4177. doi: 10. 1128/JCM.41.9.4172-4177. 2003

Brook, C. E., \& Dobson, A. P. (2014). Bats as 'special' reservoirs for emerging zoonotic pathogens. Trends in Microbiology, 23(33), 172-180. doi: 10.1016/j.tim.2014.12.004

Darriba, D., Taboada, G. L., Doallo, R., \& Posada, D. (2012). jModelTest 2: more models, new heuristics and parallel computing. Nature Methods, 9(88), 772. doi: 10.1038/ nmeth.2109

Descloux, E., Mediannikov, O., Gourinat, A., Colot, J., Chauvet, M., Mermoud, I.,... Raoult, D. (2020). Flying fox haemolytic fever, description of a new zoonosis caused by "Candidatus Mycoplasma haemohominis". Clinical Infectious Diseases, 73(7), 1445-1453. doi: 10.1093/ cid/ciaa1648
Di Cataldo, S., Kamani, J., Cevidanes, A., Msheliza, E. G., \& Millán, J. (2020). Hemotropicmycoplasmasinbatscaptured near human settlements in Nigeria. Comparative Immunology, Microbiology \& Infectious Diseases, 70(1), 101448. doi: 10.1016/j.cimid.2020.101448

Drummond, A. J., Suchard, M. A., Xie, D., \& Rambaut, A. (2012). Bayesian phylogenetics with BEAUti and the BEAST 1.7. Molecular Biology and Evolution, 29(8), 1969-1973. doi: 10.1093/molbev/ mss075

Hoelzle, K., Winkler, M., Kramer, M. M., Wittenbrink, M. M., Dieckmann, S. M., \& Hoelzle, L. E. (2011). Detection of Candidatus Mycoplasma haemobos in cattle with anaemia. Veterinary Journal, 187(3), 408-410. doi: 10.1016/j. tvjl.2010.01.016

Ikeda, P., Seki, M., Carrasco, A., Rudiak, L., Miranda, J., Gonçalves, S. M. M.,... André, M. R. (2017). Evidence and molecular characterization of Bartonella spp. and hemoplasmas in neotropical bats in Brazil. Epidemiology \& Infection, 145(10), 20382052. doi: $10.1017 /$ S0950268817000966

Katoh, K., \& Standley, D. M. (2013). MAFFT multiple sequence alignment software version 7: improvements in performance and usability. Molecular Biology and Evolution, 30(4), 772-780. doi: 10. 1093/ molbev/mst010

Machado, C. A. L., Vidotto, O., Conrado, F. O., Santos, N. J. R., Valente, J. D. M., Barbosa, I. C.,... Vieira, R. F. C. (2017). Mycoplasma ovis infection in goat farms from northeastern Brazil. Comparative Immunology, Microbiology and Infectious Diseases, 55(1), 1-5. doi: 10.1016/j. cimid.2017.08.004 
Mascarelli, P. E., Keel, M. K., Yabsley, M., Last, L. A., Breitschwerdt, E. B., \& Maggi, R. G. (2014). Hemotropic mycoplasmas in little brown bats (Myotis lucifugus). Parasites \& Vectors, 7(1), 117. doi: 10.1186/17563305-7-117

Millán, J., Di Cataldo, S., Volokhov, D. V., \& Becker, D. J. (2020). Worldwide occurrence of haemoplasmas in wildlife: Insights into the patterns of infection, transmission, pathology and zoonotic potential. Transboundary and Emerging Diseases, 00, 1-21. doi: 10.1111/tbed.13932

Millán, J., López-Roig, M., Delicado, V., SerraCobo, J., \& Esperón, F. (2015). Widespread infection with hemotropic mycoplasmas in bats in Spain, including a hemoplasma closely related to "Candidatus Mycoplasma hemohominis". Comparative Immunology, Microbiology and Infectious Diseases, 39(1), 9-12. doi: 10.1016/j. cimid.2015.01.002

Mongruel, A. C. B., Spanhol, V. C., Valente, J. D. M., Porto, P. P., Ogawa, L., Otomura, F.,... Vieira, R. F. C. (2020). Survey of vectorborne and nematode parasites involved in the etiology of anemic syndrome in sheep from Southern Brazil. Revista Brasileira de Parasitologia Veterinária, 29(3), e007320. doi: 10. 1590/S1984-29612020062
Reis, N. R., Peracchi, A. L., Batista, C. B., Lima, I. P. de, \& Pereira, A. D. (2017). História natural dos morcegos brasileiros: chave de identificação de espécies. Rio de Janeiro: Technical Books.

Santos, L. C., Vidotto, O., Santos, N. J. R., Ribeiro, J., Pellizzaro, M., Santos, A. P.,... Biondo, A. W. (2020). Hemotropic mycoplasmas (hemoplasmas) in free-ranging bats from Southern Brazil. Comparative Immunology, Microbiology and Infectious Diseases, 69(1), 101416. doi: 10.1016/j. cimid.2020.101416

Schipper, J., Chanson, J. S., Chiozza, F., Cox, N. A., Hoffmann, M., Katariya, V.,... Young, B. E. (2008). The status of the world's land and marine mammals: diversity, threat, and knowledge. Science, 322(5899), 255230. doi: 10.1126/science.1165115

Sela, I., Ashkenazy, H., Katoh, K., \& Pupko, T. (2015). Guidance 2: accurate detection of unreliable alignment regions accounting for the uncertainty of multiple parameters. Nucleic Acids Research, 43(1), 7-14. doi: 10.1093/nar/gkv318

Volokhov, D. V., Becker, D. J., Bergner, L. M., Camus, M. S., Orton, R. J., Chizhikov, V. E.,... Streicker, D. G. (2017). Novel hemotropic mycoplasmas are widespread and genetically diverse in vampire bats. Epidemiology \& Infection, 145(15), 31543167. doi: 10.1017/S095026881700231X 
